\title{
The Process of Self-Actualization of the Main Character of the Novel Perempuan Yang Menangis Kepada Bulan Hitam By Dian Purnomo's: A Review of Abraham Maslow's Humanistic Psychology
}

\author{
Mardiza Syafitri ${ }^{1, *}$ Nurizzati $^{1}$ \\ ${ }^{1}$ Indonesian Language and Literature Education, FBS University Negeri Padang \\ *Corresponding author. Email: mardizasyafitri08@gmail.com
}

\begin{abstract}
This study aims to describe the process of the storied needs of the main figures in achieving self-actualization in the novel Perempuan yang Menangis kepada Bulan Hitam. Dian Purnomo's work is seen from Maslow's humanistic psychology. This type of research is qualitative research with descriptive methods. The source of this research data is novel Perempuan yang Menangis kepada Bulan Hitam by Dian Purnomo. Data collection techniques in this study by reading and understanding novels Perempuan yang Menangis kepada Bulan Hitam dian Purnomo's work, then marks data in the form of words, clauses, sentences related to multilevel needs, and inventory the data. The results of research form of fulfillment of multilevel needs in achieving self-actualization of the main figure in the novel Perempuan yang Menangis kepada Bulan Hitam Dian Purnomo's work is as follows. (1) basic needs (physiological) found 7 data, basic needs fulfilled by the main figure in the form of the need for beverages, the need for food, the need for clothing, and the need for housing (2) the need for security found 28 data, the need for security fulfilled by the main figure includes the need to be free from fear, self-control, the need for security and protection, the need to be free from fear and anxiety, the need for conformity with the environment and the need for peace (3) the need for a sense of love and having found 10 data, the need for a sense of love and having the main character fulfilled thanks to the emotional connection between the companion figures namely dangu (Magi's best friend), Ina Bobo (Magi's mother), Tara (Magi's friend), Rega (Magi's older brother) and people from gema perempuan NGO, Mrs. Agustin who gave attention and affection (4) the need for self-esteem and appreciation found 13 data, the need for self-esteem and appreciation fulfilled by the main figure includes needs and competencies, awards in the form of recognition, praise, gaining confidence, success in society and acceptance and incompetence (5) The need for self-actualization is found 6 data, namely the success of bringing Leba Ali to prison, acceptance of his own condition for all events that have occurred, appreciation from the environment for his courage against the customs that are still practiced, and finally the recognition and admiration of the world to the figure of Magi who dare to challenge a custom.
\end{abstract}

Keywords: novel, literary psychology, self-actualization

\section{INTRODUCTION}

Literary works are the result of a creative process of an author in the form of artwork that uses ideas as the basis for developing the creative process, and uses language as its medium. The idea that the author obtains when producing a literary work is based on the experience he has gained from the reality of life in the surrounding community. Where literary works tell about the life journey of a figure in his daily life, solving the problems faced, and uncovering every problem in a good way. Satra's work is imaginative. However, literary works on the other hand explain the facts of life or the reality of life imaginaryly. In other words, imaginative literature "perfects" reality so that man better understands and behaves properly towards the reality of his life, Hidayati [3]

Literary works are born in the community on the results of the author's soul disclosure about life, events, and experiences. The experience in question could have 
come from the author or others, which was then processed as a story material so as to give birth to a literary work, Rosmila [12]. Literary works relate to the realities of people's lives in this regard. Thus, literary works are not only considered as a work of art expressed through the experiences of life in society, but also as a work of keratif that is often associated with psychiatric symptoms in this case human attitudes and behaviors. Therefore, literary works are referred to as psychiatric symptoms (illnesses). Behavior reflected through speech and deeds is empirical data or facts that become agents of a person's mental or mental state.

Wellek and Warren [15] literature is a creative activity and as one form of artwork derived from one's imagination related to the reality of life, in which there are psychiatric symptoms that can be shown through human attitudes and behaviors. Authors who have high imaginative and based on awareness and responsibility in terms of creativity as a work of art can provide an overview of life using imaginative and emotional language in the form of interaction between humans and their environment [13].

Novels are works that contain stories and present phenomena, events, facts, and imaginations in more detail and detail by the author. Each novel that is written offers a lot of interesting stories, plots, and characters to take the reader to the realm of hayalnya that seems to bring the reader in the story of the novel. In addition, novels are one of the means to express the personality that exists in society because it becomes one of the types of reading that is much in demand by readers. Novels as part of the literary world, able to display the characters in it through the content and storyline delivered in the form of writing. Various characters are shown have their own characteristics that form an interaction in the story. The character in the novel as an actualizing individual, may be seen as an attempt to better understand human behavior, since nevertheless the novel is a reflection of human life depicted with language and interesting storylines by the author.

Just like in life, the characters in the story also have personalities with all the problems. The problem can be individual (mental), as well as social (environmental). Every problem certainly has a cause, climax, and solution. Perempuan yang Menangis kepada Bulan Hitam is a novel by Dian Purnomo [1] published on January 13, 2020. The novel was written by Dian after he was awarded the 2019 Indonesian Writer Residency grant in Sumba. Dian presents a story about an educated woman who returns home after earning a bachelor's degree in agriculture at one of the universities in Yogyakarta, but upon arriving at her hometown in Sumba, the woman is confronted by a customary issue that took her independence as a woman.
Dian Purnomo was born Dian Yuliasri in Salatiga on July 19, 1976. Dian is an independent writer who has an interest in social issues, particularly women's issues and child protection. Novel Perempuan yang Menangis kepada Bulan Hitam is the 9th book he wrote after six years of vacuum. This novel is a work he produced after receiving the 2019 Indonesian Writer Residency grant in Sumba. Alumni of Criminology UI are actively bringing "Writing Class in the Park" to life, an open-air writing class that is paid in the form of good currency and currently works as a Child Protection Advocacy Specialist di Save the Children Indonesia.

The author has 15 years of experience working with the media and has previously worked at a Media Specialist in Media Indonesia, Lecturer in Creative Writing at Multimedia Nusantara University, Writing Consultant at WHO, Ministry of Health, PKBI, Islamic Relief, MAMPU (Advanced Indonesian Women for Poverty Alleviation), Associate researcher at PUSKA PA \&Kriminology UI, Broadcaster at Zenith AM Salatiga, RCTFM Semarang, TV Borobudur Semarang, and worked as Director at FeMale Radio Semarang \&Yogyakarta.

Novel Perempuan yang Menangis kepada Bulan Hitam selected in this study because it is interesting to be studied in terms of the story presented. The novel provides an overview of how one seeks to gain freedom and self-freedom from a custom that is distorted and detrimental to a woman. The novel is about a main character named Magi Diela, a woman who is a victim of the traditional tradition of catching mating or Yappa Manwine in Sumba. It is a customary tradition that kidnaps a woman to be forced to marry but in an inhumane way. Women who have been kidnapped in the tradition of Yappa Manwine are given no choice but to marry their own captors, this is due to the belief that when a woman refuses to marry, it is considered to reject a soul mate so that she will be single for life and get social punishment from the community as a family that does not know the customs that are the legacy of their ancestors.

Overnight, Magi felt that independence over him had been forcibly taken, abused by Leba Ali's men who forcibly brought Magi and raped unconscious by Leba Ali. Leba Ali is a middle-aged man who is famous for his basket eyes. Since little Magi, Leba Ali has noticed and often visited Magi's house for various reasons. No less surprising is how Ama Bobo (father) Magi turned out to play a role in the kidnapping or marriage case that befell his own daughter without telling the big family.

Being in a state of bodily harm and his self-esteem has been lost as a result of being the victim of an act of abuse from a kidnapping on behalf of custom, Magi did not stay silent to receive the treatment. He tried to send a 
letter to his family to help get out of Leba Ali's house but his father had in fact agreed that he and Leba Ali would get married. This is certainly not acceptable to Magi so the right action to have the forced marriage annulled is by running away with his own efforts. After making it out of Leba Ali's house by injuring his own hand, not making Magi get a defense from the family, especially the father and the community, the community gave insult to Magi and blamed the actions he had done as a woman who did not know the custom.

Innuendo in the form of a stamp of women who do not know the custom is always directed at him and the father who always blames him makes Magi choose to run away from home, seek the truth of the custom that has hurt his self-esteem and his rights as a woman and seek the protection that he might get out there and prove that the custom of catching marriage is very detrimental to women. In the fight for rights and gaining freedom, these needs to achieve this are well portrayed through the main character. These needs are in accordance with the theory of storied needs presented by Maslow in his theory of humanistic psychology about the theory of multilevel needs in human life in achieving selfactualization.

The process of self-actualization affects a person's psychological state. When a person's basic needs are not met, it will lead to psychological disorders. Failure to meet basic needs has a reciprocal relationship with social situations. Literature and psychology can be symbiotic in their role towards life. Both deal with the issue of man as individual beings and social beings. Both make use of the same foundation that makes the human experience a study material, Maslow [9]. More emphatically psychology and literature have a functional relationship because both study one's psychiatric state scientifically, in psychology one's psychiatric symptoms are real, while in literature is imaginative, while personality is portrayed through character. Thus it can be drawn the common thread that literary psychology is a study that views work as a psychiatric activity. Literary psychology is synonymous with psychoanalysis, which arises from Sigmun Freud's theory which was later developed and used in the study of literary psychology, such as humanistic psychology of human personality and behavior determined by motivation to achieve something.

In the study of psychology, the need gets attention for a number of psychologists. One of the most popular theories of necessity was built and developed by Abraham Maslow. According to Maslow human behavior is determined by the individual's tendency to achieve goals to make the individual's life happier and at the same time fulfilling [9]. Based on this belief, Maslow built a theory of need that came to be known as the "Hierarchy of Need". In this hierarchy of needs theory, Maslow mentions five hierarchically composed human needs. It is called hierarchy, because the fulfillment of these five needs is based on top priority.

This hierarchy of needs starts from the most basic need called D-needs or deficiency needs by Freud. Mindrop describes this need consists of; (1) The physiological needs (2) The safety needs (3) The belongingness and love needs (4) The esteem needs and end with B-needs or being needs, which means the desire to fulfill self-potential (5) The need for selfactualization. [9]

The highest hierarchy of the peak of these needs is self-actualization, one can achieve or this selfactualization will materialize if that person has met the needs under him. One will be able to achieve this need if one is able to go through difficult times that come from oneself or from outside.

Today, humanistic psychology research on maslow's multilevel needs theory has also been researched by: Deby Nur Kumalasari [6] The Inner Needs of Sajrone Text Of Anggitane BW Purba Negara Pilgrimage Film (Tintingan Psikologi Abraham Maslow). Ellyana Ilsan Eka Putri [11] Humanist in Educating (Applied Analysis of Humanistic Psychology). Mona Eka Wati and Nevi Yarni [2] Theory of Learning Based on The Flow of Humanistic Psychology and Implications on the Learning Process. Siti Shafa Marwah and Aam Abdussalam [8] Humanistic Psychological Review in Spiritual Pedagogics, Julia and Zaenal Arifin [4] SelfActualization and Educational Value in Sintha Rosse's Revenge Novel, and research conducted by Zuhra Latifa and Syafituddin [7] Crisis of Humanism in Sintha Rosse's Novel "Al-Dhill Al-Aswad".

Based on the background that has been described in the previous, the problem that wants to be observed in this study is the self-actualization of the main character in the novel Perempuan yang Menangis kepada Bulan Hitam dian Purnomo's work seen from Maslow's humanistic psychology process. This is an interesting research because it discusses human abilities in this case the main characters in the novel Perempuan yang Menangis kepada Bulan Hitam to meet the needs in order to be able to actualize himself.

\section{RESEARCH METHODS}

\subsection{Types and Methods of Research}

This type of research is qualitative research and uses descriptive methods of analysis. Descriptive method is a method of examining the status of a human group, an object, a set of conditions, a system of thought or a class 
of events in the present. The purpose of this descriptive research is to make systematic, factual, and accurate descriptions, depictions or paintings of the facts of the properties and relationships between the phenomena investigated. Descriptive method of analysis is a method that is done by describing the facts which is then followed by analysis. This method not only elaborates but also provides understanding and explanation. According to Moleong [10] qualitative researchis research that intends to understand phenomena about what is experienced by research subjects such as behavior, perception, motivation, action, etc. holistically and with descriptions in the form of words and languages, in a special context that is natural and by utilizing various scientific methods.

\subsection{Data and Data Sources}

Data collected to describe the process of fulfilling the needs in achieving self-actualization of the main character in the novel Perempuan yang Menangis kepada Bulan Hitam Dian Purnomo's work in this research is in the form of words, sentences, and discourses presented in descriptive form. This research data is the words, sentences, and speeches of story characters and the actions of story characters contained in the novel Perempuan yang Menangis kepada Bulan Hitam by Dian Purnomo. The source of this research data is novel Perempuan yang Menangis kepada Bulan Hitam dian Purnomo's work, published by the publisher PT Gramedia Pustaka Utama, Jakarta in 2020 with a total of 312 pages. The novel uses a pink cover and an abstract image as the cover of the novel Perempuan yang Menangis kepada Bulan Hitam.

\subsection{Research Instruments}

The instrument of this study is the researcher himself. Researchers recorded and collected data on humanistic psychology in the form of storied human needs (main characters) in achieving self-actualization in novels Perempuan yang Menangis kepada Bulan Hitam dian Purnomo's work using data recording sheets, after the data is collected and then processed and interpreted. According to Moleong [10] that the researcher is a planner, implementer of data collection, analysis, data interpreter, and in the end he became a reporter of the results of his research. Researchers collect data by reading, identifying, classifying, and interpreting words, phrases, clauses, and sentences that can be abstracted as data on the process of fulfilling the multilevel needs contained in the novel Perempuan yang Menangis kepada Bulan Hitam by Dian Purnomo.

\subsection{Data Collection Techniques}

The data collection of this research was conducted with the following steps. First, read and understand the novel Perempuan yang Menangis kepada Bulan Hitam by Dian Purnomo [1]. Second, marking data includes words, phrases, clauses, and sentences related to multilevel needs in the novel Perempuan yang Menangis kepada Bulan Hitam by Dian Purnomo. Third, identify data based on Maslow's storied needs found in the novel Perempuan yang Menangis kepada Bulan Hitam by Dian Purnomo. Fourth, inventory the data according to the research object, based on the format of the data inventory.

\subsection{Data Wetting Techniques}

Data sharing techniques used in this study is trianggulasi technique, which is a technique of checking the validity of data that utilizes something born from outside the data for the purposes of checking or as a comparison to the data Moleong [10]. In this study, checking or comparing the data was done by means of researchers receiving input from the results of discussions with lecturers and also input from peers in proposal seminars.

\subsection{Data Analysis Techniques}

The data that has been inventoried, will then be analyzed with the following steps;

1. Classifying data related to Maslow's storied needs in achieving the self-actualization of the main character in the novel Perempuan yang Menangis kepada Bulan Hitam by Dian Purnomo.

2. Interpreting data on Maslow's storied needs in achieving the self-actualization of the main character in the novel Perempuan yang Menangis kepada Bulan Hitam by Dian Purnomo.

3. Make inferences of the results of the analysis to see the needs of multilevel include; basic (physiological) needs, the need for a sense of security, the need to be loved and possessed, the need for self-esteem and appreciation, and the actualization of the main character in the novel Perempuan yang Menangis kepada Bulan Hitam by Dian Purnomo.

4. Make a research report on the self-actualization of the main characters in the novel Perempuan yang Menangis kepada Bulan Hitam by Dian Purnomo. 


\section{RESULTS AND DISCUSSIONS}

\subsection{Basic Needs (Physiological)}

Basic needs (physiological) are a group of needs that are most urgently fulfilled because they are related to human needs. Basic needs include the need for food, drink, shelter, sex, and so on. Basic needs are the most important needs needed by humans from birth so that these needs will be met in order to lead to the next needs.

This basic need is the need that has the most influence. For example, if an individual feels starvation or thirst then he will be encouraged to satisfy him or her first before achieving other needs. This need is different from other needs in at least two important things. First, physiological needs are the only needs that can be met even always met. Second, the characteristic of physiological needs is their ability to reappear, these needs appear constantly on a regular basis, while needs on other levels do not reappear constantly. While in a safe house, basic needs in the form of food needs are still obtained by the main figures of gema perempuan NGOs. The fulfillment of the need for food that is tescurring nature or appears constantly is illustrated in the following excerpt.

\section{"Orang-orang dari LSM Gema Perempuan mengunjunginya dua kali sehari untuk mengantarkan makanan.} [1]

The 34/TN/KD data excerpt above is the fulfillment of the main character's food needs that are met. The fulfillment of basic needs in the form of food has always been an urgent need for fulfillment because it is very influential on one's physiological. Magi's character even escaped from his home, these basic needs remained met as long as he was in a safe house. The fulfillment of basic needs (physiological) in the form of the need for food is again met by the gift of one of the NGOs Gema Perempuan. This is in accordance with Maslow's opinion on basic needs, in [9] states that basic needs (physiological) are a group of basic needs that are most urgently fulced because they are related to human biological needs. Such needs include needs: food, drink, clothing, shelter, oxygen, sex, and so on. Because the most urgent need, then before this is achieved, will not move towards the need on it.

\subsection{The Need for Security}

The need for security is a need that encourages individuals to obtain a sense of physical security, stability, stability, stability, protection and freedom from various threats from terrorists, diseases, fears, anxiety and or natural disasters. A need when an individual can feel security, tranquility, certainty, and conformity with their environment. The need for security includes the need for security, stability, protection, order, freedom from fear and anxiety, Maslow [9]. In an effort to fulfill the need for security magi main character obtained in the event of a story of self-rescue out of the surveillance environment of the character Leba Ali. In seeking this need for security, Magi figures take a variety of actions that can be said to take risks in order to ensure their safety.

Efforts to fulfill the need for a sense of security magi figures while in his own home is to try to maintain attitudes and actions that may have a bad influence and get people in his house to take an action in the form of prohibitions that will disturb his freedom again. By maintaining an attitude that will make the people who are targeted do not put suspicion on him, this need is a form of need for guarantees if it succeeds in making the people of the house believe him then the plan to escape from home will succeed. The act of keeping the attitude while in the house gives results as desired by the main character, Ama Bobo is no longer rigid when meeting with himself or no longer gives a ban on his leadership again and has now begun to give freedom of practice outside the sight of Ama Bobo to him.

\begin{abstract}
"Sementara bagi Ama Bobo, ayahnya itu tampaknya percaya bahwa dirinya sudah tunduk. Gerak-gerik ayahnya menjadi luwes, tidak lagi tegang seperti beberapa waktu belakangan" [1]
\end{abstract}

In the data excerpt 25/TN/KRA above, it is illustrated that the need for security includes the need for magi figure guarantees in making Ama Bobo no longer tense as previously achieved. This is proven by his father's attitude is now becoming more free with him. With the change in attitude shown by Ama Bobo, the need for a sense of security of the main character has been fulfilled. The change in the father's attitude also brings a change to the attitude of the main character while at home. Here the main character no longer needs to feel supervised in every move. He finally gained freedom of action. This is in accordance with Maslow's opinion [9]. The need for security is a need when an individual can feel security, tranquility, certainty, and conformity with their environment. The need for security includes the need for security, stability, protection, order, freedom from fear and anxiety. 


\subsection{The Need for Love and Sense}

The need for love and sense of belonging is a need that encourages individuals to have affective relationships or emotional bonds with other individuals, both with the same sex and with different types, in the family environment or in the community. Maslow [9] explains that the need for a sense of being stalked and possessed is a need that encourages people to have affective relationships or emotional relationships with others. A person who achieves this need is the desire to be able to feel warmth, hospitality, love and love each other. The need for a sense of love and belonging can be obtained from family, friends, and spouses. Living people will get the first love of the core family, this form of love can be categorized in any form. One of them is the form of attention received.

After leaving the hospital, the information that Magi had attempted suicide by biting his own wrist immediately spread throughout the village, no exception to the ears of his friends, thus making Magi's friends come to give encouragement.

"Beberapa kawan Magi datang
mengunjungi untuk memberikan
semangat. Magi senang sekali
menemuimereka"[1]

In the data excerpt $19 / \mathrm{TN} / \mathrm{KCM}$ above, it is illustrated that magi figure not only get affection and attention from his family but he also gets it from his friends. The form of presence and encouragement from friends to magi figures is the fulfillment of the need for a sense of love and belonging that is met by his needs. With the presence of those who visit directly to the house and the encouragement gives an emotional connection between the main character and his friend. The emotional connection that is formed brings the main character to feel the warmness. This is in accordance with Maslow's opinion [9] explaining that the need for a sense of being stalked and possessed is a need that encourages humans to have affective relationships or emotional relationships with others. A person who achieves this need is the desire to be able to feel warmth, hospitality, love and love each other.

\subsection{The Need for Self-Esteem and Self-Esteem}

The need for self-esteem and self-esteem, Maslow [9] explains that these needs are divided into two, first, self-respect or appreciation which include: the desire to acquire competence, the presence of confidence, having freedom, self-reliance, mastery, sufficiency, achievement, dissension, freedom, and strong personality. Second, there are awards from others that include: prestige (success in society), recognition, acceptance, attention, standing, good name, and appreciation. Self esteem is an assessment that describes the extent to which an individual considers himself or herself to be valuable, competent, and capable.

Upaya dalam memenuhi kebutuhan akan harga diri dan penghargaan yang didapatkan oleh tokoh Magi terjadi disaat dirinya berada di rumah Mama Mina. Ketika dirinya sampai di rumah Ma Mina, tokoh Magi belum sepenuhnya percaya bahwa dirinya telah berhasil kabur dari Leba Ali dan Ama Bobo. Tokoh Magi menceritakan semua peristiwa yang telah di alaminya yang seakan dirinya masih merasa berada di rumah Leba Ali, semua cerita yang disampaikan tokoh Magi kepada Ma Mina membuat Ma Mina memeluk tokoh Magi sembari memberikan kekuatan.

"Mama Mina memeluk Magi. "Ko
perempuan kuat,. Ko perempuan
hebat. Ketika ini semua berlalu, ada
banyak orang yang akan berterima
kasih karena ko begitu berani." [1]

In the data excerpt 27/TT/KHP above, it is illustrated that the character Ma Mina gave recognition and appreciation to the Magi figure for the brave actions that have been chosen by the Magi figure. Magi's courageous actions will not only have a good impact on himself but will also have an impact on all women who may have the same luck as him. Ma Mina's character here assures that Magi's actions are actions that should indeed be taken by a brave and powerful woman like herself. When the character Ma Mina gives praise for this action, it can be said that the Magi figure has fulfilled the need for self-esteem and appreciation obtained from the character Ma Mina. This is in accordance with Maslow's opinion [9] explaining the appreciation of others that includes: the need to achieve achievements in life so as to obtain awards from other parties. So, if this need is achieved, then the individual feels more confident, feels strong, feels capable and feels useful.

\subsection{The Need for Self-Actualization}

In the novel Perempuan yang Menangis kepada Bulan Hitam the need for self-actualization of the main character is seen at a time when the main character achieves his success in fighting the customary shackles that have harmed him. His desire to criminalize Leba Ali 
and prove to the father and the environment that yappa mawine custom or marriage arrest is a criminal crime to women can finally be realized. The need for selfactualization is pursued by the main character in order to be fulfilled by making himself a temeng or victim to attract Leba Ali in order to be convicted.

"Sekarang, Magi sendiri yang
memastikan bahwa seluruh dunia tahu
kebobrokan Leba Ali dan betapa
kejamnya perlakuan terhadap
perempuan di tanahnya. Magi
membangunkan seluruh dunia dengan
menjadikan dirinya sebagai simbol
perelawanan." [1]

In the data excerpt 60/TN/AD above, illustrated efforts to fulfill the need for self-actualization of Magi figures. Here magi figure awakens his inner potential as an attempt to fight off all the actions of Leba Ali on behalf of a custom. The action chosen by the main character who makes himself or herself a symbol of resistance is a form of the need for the actualization of the main character. Choosing to make himself a symbol of resistance is a bold act, the main character realizes that if it was not himself who had to fight then there would be no woman in his land who would have the courage to fight the custom more than he is now. This is in accordance with Maslow's opinion [14] about the characteristics of a person who actualizes himself, in the quote, the main character has the characteristics of the person who actualizes himself that is first, the efficient perception of reality, in which the main character is able to judge the siituasi accurately and honestly. Second, acceptance: self, others, and the environment, in which the main character accepts the shortcomings of oneself as well as the weaknesses of others and the opposition of life. Third, Spontaneity: where the main character cannot be banned regarding the actions that have been chosen in the desire to bring Leba Ali into prison. Fourth, Task orientation, in which the main character proves that it has a purpose and personal problems that must be solved.

\begin{abstract}
"Mendapati Leba Ali meringkuk di dalam penjara sudah cukup baginya. Ini adalah pesan yang ingin Magi sampaikan kepada setiap orang yang mencoba merampas hak orang lain." [1]
\end{abstract}

The quote in the data 63/TN/KAD above, is the need for self-actualization of the main figure. The quote that says finding Leba Ali curled up in prison is enough for him to be an achievement of the success of his sacrifice against a man who deprived women of their rights in the name of custom. Maslow explained that a person is able to achieve this need if he is able to go through difficult times that come from himself or from outside. This is in accordance with Maslow's opinion [14] that the orientation of the goal, the main character has fulfilled his purpose in prosecuting and putting Leba Ali in prison. Furthermore, Maslow [5] about the peak experience is to define the peak experience as moments when the world seems intact and the person is in tune with it, changing the perception of the world for the better.

\section{CONCLUSION}

Based on the results of research and discussion about self-actualization in the novel Perempuan yang Menangis kepada Bulan Hitam Dian Purnomo, it can be concluded as follows.

1. The basic (physiological) needs of the main character contained in the novel Perempuan yang Menangis kepada Bulan Hitam Dian Purnomo found 7 data. Basic needs are met by the main character in the form of the need for drinks, the need for clothing, the need for food, and the need for housing.

2. The need for a sense of security of the main character contained in the novel Perempuan yang Menangis kepada Bulan Hitam by Dian Purnomo found 28 data. The need for security fulfilled by the main character in trying to protect himself from all forms of leba Ali and Ama Bobo's actions to him includes the need to be free from fear, self-mastery, assurance and protection, free from fear and anxiety, conformity with the environment, and peace.

3. The need for a sense of belonging and belonging contained in the novel Perempuan yang Menangis kepada Bulan Hitam Dian Purnomo's work found 10 data. The need for a sense of love and belonging is fulfilled thanks to the affection given directly by dangu figures as friends, Ina Bobo, Tara, Rega, and people from the LSM Gema Perempuan.

4. The need for self-esteem and appreciation contained in the novel Perempuan yang Menangis kepada Bulan Hitam Dian Purnomo's work found 13 data. The need for self-esteem and appreciation fulfilled by the main figure in the form of the need for competence, awards in the form of recognition, praise, confidence, success in society and acceptance, and incompetence. 
5. Self-actualization of the main character in Perempuan yang Menangis kepada Bulan Hitam Dian Purnomo's work found 5 data representing the form of self-actualization of the main character. Self-actualization in the form of success in bringing Leba Ali to prison, acceptance of his own condition for all events that have occurred, appreciation from the environment for his courage against the customs that are still practiced, and finally the recognition and admiration of the world to the figure of Magi who dare to challenge a custom.

\section{AUTHORS' CONTRIBUTIONS}

The author thanks Dr. Nurizzati,. M.Hum., who have provided guidance and thought to direct the author in completing this research. The author also thanked both, Dr. Yenni Hayati, S.S., M. Hum., and Dr. Abdurrahman,. M.Pd. who have provided suggestions and inputs for the perfection of the author's writing.

\section{REFERENCES}

[1] Purnomo, Dian. 2020. Perempuan yang Menangis kepada Bulan Hitam. Gramedia Pustaka Utama

[2] Ekawati, Mona dan Nevi Yarni. 2019. Teori Belajar Berdasarkan Aliran Psikologi Humanistik dan Implikasi pada Proses Belajar Pembelajaran. Jurnal: Volume 2 No. 2.

[3] Hidayati, Eka Suci, Dessy Wardiah, \& Arif Ardiansyah. 2021. Klasifikasi Emosi Tokoh dalam novel Titian Takdir Karya W Sujani (Kajian Psikologi Sastra). Jurnal: Universitas PGRI Palembang. Vol. 5 No. 1.
[4] Julia \& Arifin, Zaenal. 2020. Aktualisasi Diri dan Nilai Pendidikan dalam Novel Dendam Si Yatim Piatu karya Sintha Rosse. Jurnal: Universiyas Indraprasta PGRI.

[5] Jarvis, Matt. 2018. Teori-Teori Psikologi: Pendekatan Modern untuk Memahami Perilaku, Perasaan, dan Pemikiran Manusia. Bandung: Nusa Media.

[6] Kumalasari, Deby Nur. 2018. Kabutuhan Batin Sajrone Teks Film Ziarah Anggitane Bw Purba Negara (Tintingan Psikologi Abraham Maslow)

[7] Latifa, Zuhra dan Syarifuddin. 2021. Krisis Humanisme Dalam Novel "Al-Dhill Al-Aswad" Karya Najib Kailani (Kajian Humanisme Abraham Maslow). Jurnal: An-Nahdah Al-'Arabiyah, Volume 1 No. 1 .

[8] Marwah, Siti Shafa dan Aam Abdussalam. 2020 Tinjauan Psikologis Humanistik dalam Pedagogik Spiritual. Jurnal: Al-Musannif, Vol. 2, No. 1.

[9] Minderop, Albertine. 2018. Psikologi Sastra. Jakarta: Yayasan Pustaka Obor Indonesia.

[10] Moleong, Lexy. J. 2010. Metodologi Penelitian Kualitatif. Bandung: Remaja Risdakarya.

[11] Putri, Ellyana Ilsan Eka. 2018. Humanis dalam Mendidik (Analisis Terapan Aliran Psikologi Humanistik). Jurnal: Tarbiyatuna, Vol. 2 No. 2.

[12] Rosmila, Ana, Enang Dwi Sulityowati, \& Norma Atika Sari. 2020. Kepribadian Tokoh Utama dalam Novel Kanvas karya Bintang Purwanda: Tinjauan Psikologi Sastra. Jurnal. Universitas Mulawarman. Vol. 4 No. 2

[13] Setiaji, Aria Bayu. 2019. Kajian Psikologi Sastra dalam Cerpen "Perempuan Balian" Karya Sandi Firli. Jurnal: Lingue. Vol. 1 No. 1.

[14] Wilcox, Lynn. 2018. Psikologi Kepribadian: Menyelami Misteri Kepribadian Manusia. Yogyakarta: IRCISoD.

[15] Wellek, Rene dan Austin Warren. 2016. Teori Kesusastraan (Di Indonesiakan oleh Melani Budianta). Jakarta: PT Gramedia Pustaka-Utama 